\title{
Comparing child protection decision making in England and Finland: Supervised or supported judgement?
}

\author{
Rachel Falconer and Steven M. Shardlow \\ School of Social Science \& Public Policy, Keele University, UK
}

Rachel Falconer is a Doctoral Student in Social Work in the School of Social Science \& Public

Policy at Keele University, UK. Address: School of Social Science \& Public Policy, Keele

University, Keele, Staffordshire, ST5 5BG, UK. [email: r.l.falconer@keele.ac.uk]

Steven M. Shardlow is Professor of Social Work and Head of the School of Social Science \& Public Policy at Keele University, UK. Address: School of Social Science \& Public Policy, Keele University, Keele, Staffordshire, ST5 5BG, UK. [email: s.m.shardlow@keele.ac.uk] 
JOURNAL OF SOCIAL WORK PRACTICE

COMPARING CHILD PROTECTION DECISION MAKING

\title{
Comparing child protection decision making in England and Finland: Supervised or supported judgement?
}

\begin{abstract}
Systems for the protection of children have evolved differently across nation states. Studies have identified contrasting system 'orientations', related to how child protection problems are framed and how organisations respond in different contexts. In this study, the influence of national and organisational factors on practice-level decision reasoning by social workers has been compared. Interviews were conducted with 30 child protection social workers in sites across England and Finland, structured around two hypothetical case vignettes. While similarities were observed in how the social workers responded to the vignettes, there were differences in the nature and extent of managerial involvement described, with the English social workers appearing to rely on managerial input for decision making to a greater extent than the Finnish social workers. These findings suggest evidence for two distinct organisational approaches to decision making: 'supervised' and 'supported' judgement. Here, supervised judgement describes a hierarchical, 'top-down' form of decision making, while supported judgement describes a more horizontal and shared decision making approach. The lens of comparative methodology has revealed how these organisational factors come into play in different child protection systems. The practice implications of supervised, manager-led approaches to decision making, as contrasted with supported, team-led approaches, are discussed.
\end{abstract}

Keywords: social work; child protection; decision making; comparative research; vignettes 


\section{Introduction}

The abuse and neglect of children are social problems present in societies globally, whether acknowledged or not. In societies that possess a developed form of social work, varied systems have emerged to protect children either identified or suspected of being at risk of abuse or neglect. Several explanations for this variation have been proposed; for example, Lorenz (1994) has argued that contrasting welfare models and structural factors shape distinct approaches to social work practice in particular jurisdictions. Gilbert (1997) has suggested that differences can be related to the 'orientation' of the child protection system, which influences how child protection problems are framed, the nature of state intervention and the relationship between the state and families. Differences in national policy orientation also impact on micro-level practice, in particular, by affecting social workers' decision reasoning (Keddell, 2014). What is less clear, however, is how and the extent to which national policy contexts affect social workers' judgements and decision reasoning, as compared to their organisational environment, individual cognitive or group decision making processes.

In this article we present findings from an exploratory investigation of how social workers in two European countries, England and Finland, each with distinctive and developed approaches to welfare, approach decision making in child protection. The overall study objective was to identify any indications of difference or similarity in approaches to decision making between social workers in these countries, and to explore factors that may account for any such differences or similarities in approach. Specifically, we have explored the role of macro and meso-environmental factors in decision making. While case specific information and individual/decision maker factors are also known to impact the decision making process, we 
JOURNAL OF SOCIAL WORK PRACTICE

COMPARING CHILD PROTECTION DECISION MAKING

were principally concerned with if and how national child protection systems shape

organisational contexts, and whether organisations may have the ability to promote a particular orientation of practice, independent of the wider child protection system. In view of these objectives, the research questions guiding this article were twofold:

1. Is there a difference in how social workers in England and Finland approach decision making?

2. What factors do social workers identify as being influences on their judgement?

In light of existing research on decision variability (Keddell, 2014), we expected there may be three possible outcomes of the study. First, social workers in both countries may be seen to approach decision making in a variety of ways, with no organisational or national pattern; this could suggest that decision making is a highly individualised activity, and therefore individual/decision maker factors may be a leading input in the overall decision making process. Second, national differences may be observed in how the social workers approach decisions, suggesting that national context is a key factor in decision making. Third, patterns may be observed relating to how social workers within sites in England and Finland approach decisions; this could suggest that organisational factors play an important role in decision making, irrespective of national context.

The data presented here originated from a more extensive comparative study of child protection decision making in England and Finland, nations described as 'child protection'orientated and 'family service'-orientated respectively (Gilbert, 1997). This more extensive study was based on interviews, structured using two case vignettes, with 30 qualified social workers at sites across England and Finland. Selected findings are presented below and support a 
JOURNAL OF SOCIAL WORK PRACTICE

COMPARING CHILD PROTECTION DECISION MAKING

conceptualisation of two distinct approaches to decision making, identified within the two samples: supervised and supported judgement. The findings further suggest that the contrasting approaches may be related to organisational factors, including supervision arrangements and the way teams are structured. However, such organisational factors, as well as the propensity for social workers to seek managerial approval for decisions, also appear to be influenced by the wider environmental context. The potential implications of the contrasting approaches are discussed, and we conclude by reflecting on whether organisations, regardless of their national context, may have the ability to adjust working arrangements to promote a more supportive decision making environment.

\section{Literature review}

There is an extensive research literature about decision making in social work and child protection, which includes theoretical and descriptive studies (Baumann, Dalgleish, Fluke, \& Kern, 2011; De Bortoli \& Dolan, 2015; Helm \& Roesch-Marsh, 2017; Taylor, 2012); empirical studies, which utilise both qualitative and quantitative methods (Holland, 1999; Saltiel, 2016; Stokes \& Schmidt, 2012); supplemented by a growing body of comparative research (Benbenishty et al., 2015; Berrick, Dickens, Pösö, \& Skivenes, 2016; Soydan, 1995).

Much of this literature describes two broadly contrasting models of decision making in social work: analytical and technical-rational models; and naturalistic, experiential and intuitive models (Hackett \& Taylor, 2014; Munro, 2002; Platt \& Turney, 2014; van de Luitgaarden, 2009). Technical-rational and analytical models depict decision making as a rational activity, grounded in research and factual evidence, and guided by logic or actuarial risk calculations. A number of studies have explored the applicability of such models, including structured 
JOURNAL OF SOCIAL WORK PRACTICE

COMPARING CHILD PROTECTION DECISION MAKING

approaches to child protection decision making. For example, Gillingham and Humphreys (2010) observed that many practitioners did not use structured decision tools as intended by their authors, which undermined the accuracy of the instruments. Similarly, Hackett and Taylor's (2014) study revealed that social workers tended to use analytical reasoning largely as a 'check' for decisions made using intuitive approaches. More recently, debates surrounding the role of heuristics and bias in professional judgement have again highlighted the limitations of rational, 'expected utility' decision making models, when applied to social work (Taylor, 2017).

By contrast, naturalistic, experiential and intuitive models emphasise the role of professional experience and personal values in decision making. For example, a research review by Platt and Turney (2014) identified a combination of factors that influenced naturalistic reasoning in threshold decisions, which included information about the child and family, the contribution of multi-agency professionals, structural and decision maker factors, each of which interacted to influence social workers' processes of 'sense-making' when forming judgements. A similar model is that of 'decision making ecology', which proposes that influences including case factors, organisational factors, external factors and decision maker factors combine to shape the overall decision outcome (Baumann et al., 2011). While there has been much progress in the theoretical development of such models in recent years, there is less empirical evidence focused on the role of macro and meso-contextual factors in decision making. However, within this existing research, evidence suggests that both national and organisational contexts can impact social workers' judgement and decision making in different ways.

\section{The national context}


JOURNAL OF SOCIAL WORK PRACTICE

COMPARING CHILD PROTECTION DECISION MAKING

In an a comparative study based on vignettes, Soydan (1995) identified clear differences in how English and Swedish social workers assessed a hypothetical migrant family, which the author related to variations in cultural-relativity within the two nations. Differences were also detected in the decision making approaches of social workers in Canada and Israel (Benbenishty, Osmo, \& Gold, 2003), while Benbenishty et al. (2015), in a later study, observed country specific differences in professional attitudes across Israel, Spain, Northern Ireland and the Netherlands. A further illustration of such difference includes the large-scale comparative study by Burns, Pösö, and Skivenes (2016), which identified contrasting approaches to child removal decisions across eight high-income countries. In a related article by Berrick et al. (2016), the authors noted that differences in processes surrounding child removal in California, England, Norway and Finland impacted how social workers' made decisions, as well as their confidence in the final decision outcome.

\section{The organisational context}

The significance of organisational factors in decision making was highlighted by Munro (2011), who discussed how innovative organisational approaches, such as the 'Reclaiming Social Work' model developed in Hackney, England, could be replicated elsewhere to promote good practice. In an earlier study, Munro and Hubbard (2011) reported on findings drawn from practitioner and service user surveys, which suggested that organisational systems and staff working conditions, including caseload size and having space and time for reflection, influenced decision quality. In a later study by Braye, Preston-Shoot, and Wigley (2013), practitioners described how their decisions were informed by factors including agency policies and procedures, as well as advice provided in agency supervision. Similarly, in an ethnographic study of a North London local 
JOURNAL OF SOCIAL WORK PRACTICE

COMPARING CHILD PROTECTION DECISION MAKING

authority, Whittaker (2011) observed that social workers used a variety of organisational resources to aid decision making, including strategies such as 'upwards delegation' to managers and close adherence to agency procedures. It was suggested that practitioners used such strategies as forms of social defence, to overcome the day-to-day challenges and inherent anxieties of child protection social work.

It is possible that the social defences identified by Whittaker (2011) may be a particular feature of the English child protection system, given the broader context of media and political debates surrounding child protection in England (Warner, 2014). Arguably, this scrutiny and demand for accountability is absent, to the same extent, in other national contexts. Indeed, in Berrick et al's (2016) study, it was suggested that practitioners in England used more vertical structures of institutional support and were more reliant on managers to authorise their decisions, compared to Finnish practitioners. This would again suggest that organisational structures of decision making are closely linked to national contextual factors.

\section{Methods}

The research presented in this article was part of a more extensive comparative study of child protection decision making in England and Finland, conducted between 2016 and 2017, in partnership with researchers at the University of Eastern Finland. Data was collected using questionnaires and vignette-based interviews with qualified social workers responsible for

conducting child protection assessments. Ethical approval for the study was granted by Keele University and where requested, by individual local authorities and municipalities.

\section{The sites}


JOURNAL OF SOCIAL WORK PRACTICE

COMPARING CHILD PROTECTION DECISION MAKING

England and Finland were selected as the comparator nations for the study as previous research has assigned contrasting orientations to their respective child protection systems (Gilbert, 1997). This would suggest there could be differences between the two national contexts that may impact on practitioner decision making. For example, England has been described as having a 'child protection'-orientated system, an approach which frames child abuse in terms of individual moral failings and is marked by an adversarial relationship between parents and the state. In contrast, Finland's child protection system has been described as 'family service'-orientated, an approach which sees child abuse as the consequence of wider social issues, and is characterised by greater partnership between the state and parents (Gilbert, 1997). More recently, Gilbert, Parton, and Skivenes (2011) and Parton (2017) updated this analysis and noted examples of convergence in child protection systems internationally, alongside the emergence of a third, 'child focused'-orientation. In light of these characterisations, the attribution of these 'orientations' were taken into account when interpreting the results of this study. Within England, social workers were recruited from four local authorities in the North and Midlands of the country; three of which were predominantly rural, one of which was largely urban and more ethnically diverse. In Finland, social workers were recruited from three municipalities in the Eastern and Southern regions, all of which had lower population densities than the English local authorities.

[Table 1 near here]

\section{The samples}

In both England and Finland, research participants were recruited through senior staff, who were approached by email and were asked to disseminate interview invitations to child protection 
JOURNAL OF SOCIAL WORK PRACTICE

COMPARING CHILD PROTECTION DECISION MAKING

social workers employed by their local authority or municipality. In total, 15 English social workers and 15 Finnish social workers participated in the study (see Table 1). All of the Finnish social workers were educated to Master's level, this being the required qualification to practice as a professional social worker in the country. In England, six participants were educated to Master's level, while the remaining participants were educated to Bachelor's or Postgraduate Diploma level. One-to-one interviews were arranged and in most cases took place at the participants' place of work, to recreate a realistic working environment. In Finland, all participants were provided with translated background information about the study and translated case vignettes. All but one Finnish interview required some level of verbal translation, which was provided by research colleagues from the University of Eastern Finland, with specialist knowledge of child protection social work. All English participants worked in teams responsible for conducting child welfare/child protection assessments and interventions following initial filtering by a separate team. One local authority ('local authority 2') had adopted a systemic approach to practice, which involved social workers and specialists working closely together in small teams (Cross, Hubbard, \& Munro, 2010). In Finland, two social workers worked in teams responsible for receiving and processing 'notifications' (the closest translation for 'referrals'), while the rest of the participants worked in teams responsible for conducting child welfare/child protection assessments and interventions after initial filtering.

\section{Data collection and analysis}

Participants first completed a questionnaire which included questions about their education, level of experience and previous relevant positions. Participants were then asked to read and comment on two vignettes of hypothetical referrals/notifications, constructed by the principal researcher 
JOURNAL OF SOCIAL WORK PRACTICE

COMPARING CHILD PROTECTION DECISION MAKING

(see Table 2). While constructed vignettes cannot reveal what participants would do in a realworld situation, they have been shown to be an effective method for exploring social workers' views and decision making intentions from a cross-national perspective, while the standardised elicitation material can aid data analysis and comparison (Soydan \& Stål, 1994).

[Table 2 near here]

After reading each vignette, participants were asked to describe the main issues in each case, how serious they perceived the case to be and how they would respond. The vignettes were designed to include uncertainties in order to promote discussion and potentially different interpretations from the participants. In the final part of the interview, participants were asked open questions about their work. These included questions about how referrals/notifications were responded to in their organisation, the support services offered to families, the types of dilemmas they experienced in their work and how they dealt with these dilemmas. Each interview lasted approximately 40 minutes on average, with over 20 hours of data collected in total. All interviews were audio-recorded and transcribed by the principal researcher. Transcripts were coded using NVivo 10 qualitative data analysis software, from which key themes were developed.

\section{Results}

The analysis is presented below in relation to the two guiding research questions for this article.

Quotations have been selected as representative illustrations of participants' opinions, or as indicators of opinions found to be divergent from the samples in each country. 
JOURNAL OF SOCIAL WORK PRACTICE

COMPARING CHILD PROTECTION DECISION MAKING

In response to the first research question, 'Is there a difference in how social workers in England and Finland approach decision making?', the results indicate both differences and similarities between and within the English and Finnish samples. For example, in relation to the case vignettes, participants' responses appeared broadly consistent across all sites. In response to vignette 1 , for instance, participants identified similar concerns surrounding the arguments at home, the fact the mother had previous children removed, financial pressures and possible developmental delay in the youngest child:

The main concerns would be around domestic abuse, the fact Kate [the mother] and her partner are arguing... financial concerns, she's asking for support. The fact she's had two previous children taken into care, we would need to explore the reasons why. That there may be developmental issues in relation to the 18-month-old child...

English participant 3, local authority 2

[T]here is this background that there have been children taken into care before, and placed in out-of-home care perhaps. And then there is this worry, might there be violence in the family? And then there is this worry about the children, the youngest is one and a half years old, and is so small...

Finnish participant 14, municipality 3

Similarly, in response to vignette 2, participants discussed the risks of suicide ideation and possible exploitation linked to the online relationship. All participants said they required 
JOURNAL OF SOCIAL WORK PRACTICE

COMPARING CHILD PROTECTION DECISION MAKING

further information, and their next steps would involve making contact with the parents and children, gathering information and where necessary, escalating or referring to other agencies.

Differences between the English and Finnish samples emerged surrounding processes for obtaining consent for intervention in each case. In England, obtaining consent was often described in terms of procedural formality, while in Finland, gaining consent was more often described as a way of establishing partnership with families:

[W]e're not at child protection stage at the moment... we don't have any consent to do any other checks other than on our own systems, so I couldn't really do much more, without that consent...

English participant 6, local authority 2, discussing case vignette 1

I would be in contact with the mother, before I reach out to any other officials, because I would not like to go behind the mother's back before I would have had the opportunity to tell her that I'm worried.

Finnish participant 9, municipality 2 , discussing case vignette 1

Differences between the samples were also noted in response to vignette 2 , when participants described their first steps in responding to the case. In England, a fifth of participants discussed seeking advice from their manager, with a view to holding a strategy discussion (as a precursor to initiating a child protection conference). In Finland, though participants recognised the gravity of the child protection concerns, no participants referred to such managerial involvement. 
In response to the second research question, 'What factors do social workers identify as being influences on their judgement?', further differences between the samples were identified. For example, while processes for receiving and handling referrals/notifications appeared broadly similar in both countries, a key difference was the fact that in Finland, many participants referred to the role of their 'partner' or 'pair' in the assessment process. Such responses were noted in different municipal areas and refer to a system in Finland where social workers may work in partnership with a sosionomi on cases; that is, a degree-educated family welfare specialist who does not have a Master's level social work qualification. Although some English participants also discussed attending home visits with a colleague, such joint-visits appeared to be conducted for reasons of safety, rather than because of any established joint-working relationship. This could indicate that Finnish social workers' judgements may be more strongly influenced by work partners and colleagues, as illustrated below:

So the social worker is the one who leads the [assessment] process, and makes the decision. But of course they reflect with the pair... In the most complicated cases they take this case into the team, and reflect, and assess together.

Finnish participant 2, municipality 1

I make the decision how it [the assessment] goes. But of course I have this partner, and we talk together... And then if it's necessary we have this team [meeting] every Tuesday, I can also talk there. 
In contrast, many English participants referred to the influence their manager had on their judgement; for example, when providing advice in supervision or when authorising assessment decisions:

I don't get authority to sign assessments off and say, 'Yes, this is what I or another social worker thinks', that decision is left to the manager... We have our regular supervisions where you bring cases and make case decisions there as well.

English participant 10, local authority 3

Linked the above, clear differences were noted in the sources of support participants referred to when asked how they deal with difficult decisions or dilemmas. For example, two thirds of the English participants stated they would approach their manager for support in the first instance, and it was clear this support was valued:

I've got my manager, who's very good actually... she can offer really good advice about the way to take a case or other things you can try.

English participant 1, local authority 1

$[\mathrm{M}] \mathrm{y}$ first port of call would be my manager, you know, she'll always spare time for you if you're struggling with anything. 
JOURNAL OF SOCIAL WORK PRACTICE

COMPARING CHILD PROTECTION DECISION MAKING

In Finland, while the support of managers was discussed, over two thirds of participants stated they would first seek support from their work partner and/or colleagues:

First of all I would discuss with my working partner, and after this I would discuss with some other social worker... I think that we can handle most issues together with other social workers, discussing this way. So we don't always need our manager's help.

Finnish participant 13, municipality 2

We have our own teams where we can discuss with our co-workers, and also our manager... and once in in a month, we also have this kind of group supervision where we can talk about these issues.

Finnish participant 7, municipality 2

The primary reference to hierarchical, managerial support within the English responses, as compared to the more horizontal, team-led support discussed by the Finnish participants, indicates a difference in decision making approaches across the two samples. Yet, while the influence of managers appeared dominant in England, over half of the English participants also mentioned the support of their colleagues, particularly in local authority 2 , which had implemented a systemic way of working based around small teams. This may suggest that the way teams are structured can influence whether a culture of manager-led or team-led judgement dominates: 
JOURNAL OF SOCIAL WORK PRACTICE

COMPARING CHILD PROTECTION DECISION MAKING

I've got personally two other social workers [in my team] as well as a social work assistant. And we're always talking about possible options we can go to with families, so that's really useful and helps us offload.

English participant 3, local authority 2

A further difference was the fact that in Finland, participants from all three sites referred to external supervision as being an important source of support for decision making. This external supervision was provided monthly by an independent professional to teams, as opposed to individuals, and offered an opportunity for practitioners to discuss cases and receive advice and support from colleagues and the leading supervisor. By contrast, such external supervision arrangements were not discussed by the English participants; instead, the supervision described was provided one-to-one by line managers. Therefore, as the supervision described by the Finnish participants was team-based, compared to the manager-led supervision referred to by the English participants, this again supports an apparent difference between decision making approaches within the two countries.

\section{Discussion}

The aims of this article were to identify if there were differences or similarities in social workers' approaches to decision making in England and Finland, and if so, what factors may be influencing these differences or similarities. The results appear to support existing studies which have highlighted the role of environmental factors in the decision making process. For instance, differences were observed in how the English and Finnish participants approached and obtained advice for decisions, which supports the findings of Benbenishty et al.'s (2015) research, 
JOURNAL OF SOCIAL WORK PRACTICE

COMPARING CHILD PROTECTION DECISION MAKING

regarding the influence of national context on social work decision making. At the same time, differences were also observed between sites within the two countries; for example, related to the fact one English local authority had adopted a systemic approach to practice. This finding appears to support the conclusions of Munro and Hubbard's (2011) study, regarding the influence of organisational systems on decision making processes.

When considering the data relating to the case vignettes specifically, it must be noted that the vignettes were designed to elicit discussion about processes of decision making, rather than decision outcomes, and so it is perhaps understandable that similarities were observed in the participants' responses. However, differences did emerge in relation to procedural matters, for example, regarding processes for obtaining consent or having assessments authorised by managers. These findings appear to support claims made elsewhere regarding the lower levels of discretion and more proceduralised nature of child protection social work in England, as compared to Finland (Berrick, Peckover, Pösö, \& Skivenes, 2015; Hearn, Pösö, Smith, White, \& Korpinen, 2004). Similarly, references to partnership in many of the Finnish interviews appear to support the characterisation of Finland's child protection system as being more family serviceorientated in approach (Gilbert, 1997).

As regards the factors social workers identified as being influences on their judgement, it is significant that all participants referred to the support offered by other people, whether this be managers, work partners, team colleagues or external supervisors. This finding supports theoretical frameworks such as decision making ecology (Baumann et al., 2011), which emphasise the role of the wider external environment in the decision making process. Indeed, social work necessarily involves working with multi-agency colleagues, managers and team members, alongside the child and family, when forming judgements; these multiple influences 
JOURNAL OF SOCIAL WORK PRACTICE

COMPARING CHILD PROTECTION DECISION MAKING

should not therefore be underestimated when developing decision making models. This issue is discussed by Helm and Roesch-Marsh (2017), who have argued that judgement and decision making must be seen to occur in teams and groups, and in defined organisational systems.

The findings of this study, though small in scale, highlight an apparent difference in approaches to decision making within the English and Finnish samples, a distinction we have characterised using the terms supervised and supported judgement. According to this conceptualisation, supervised judgement describes a form of hierarchical decision making, whereby social workers rely mainly on managerial input to guide their actions in difficult cases. Supported judgement then describes a more horizontal decision making approach, in which social workers use a range of support sources to guide their actions, including input from colleagues, multi-agency partners and external supervisors, as well as managers.

The references to managers signing off assessments and being the primary resource for advice in England are evidence of the presence of supervised judgement in this context; this observation supports findings by Berrick et al. (2016), regarding the more vertical structures of decision making accountability in England, as compared to Finland. For example, statutory guidance accompanying England's Children Act 1989 states that social workers should 'decide the nature and level of the child's needs', and '[t]he social work manager should challenge the social worker's assumptions as part of this process' (HM Government, 2015, p. 24). By contrast, Finland's Child Welfare Act 2007 states that social workers, rather than managers, are responsible for deciding whether a child should become a child welfare client. Within the Finnish sample, participants were more likely to discuss the support offered by their partner and team in the first instance, followed by the support of managers and external supervisors, indicating a dominance of the supported judgement approach. This suggests social workers in 
JOURNAL OF SOCIAL WORK PRACTICE

COMPARING CHILD PROTECTION DECISION MAKING

Finland may have a wider support network for decision making, which could be related to organisational systems; for example, having access to regular team-based supervision, as well as a cultural and legislative environment that is less reliant on manager-approved audit trails for case decisions.

Although examples of supported judgement were more common in the Finnish sample, a number of the English participants also referred to the support of their team and colleagues, particularly in local authority 2 , which had adopted a systemic approach to practice. This could suggest that despite a more hierarchical decision making culture in England overall, it may be possible to promote supported judgement by adjusting organisational structures and working arrangements. Indeed, while it is recognised that the support of managers is vital in child protection work and should not be devalued, it is also possible that restrictive decision making processes may impact on professional development. For example, in her review of child protection in England, Munro commented:

Decision-making on cases is frequently the responsibility of th[e] manager, despite the manager often not knowing the child and family very well, if at all. This leaves the social worker in an awkward predicament, holding case responsibility, but with little autonomy for decision making... A common experience amongst social workers is that the few supervision opportunities are dominated by a managerial need to focus on performance, for example, throughput, case closure, adhering to timescales and completion of written records. This leaves little time for thoughtful consideration of what is happening in the lives of children and their families. (Munro, 2011, p. 115) 
JOURNAL OF SOCIAL WORK PRACTICE

COMPARING CHILD PROTECTION DECISION MAKING

In most everyday cases, managerial involvement in decisions will vary depending upon the complexity of the case or the experience of the worker. However, the findings of this study suggest that small organisational changes, such as increasing opportunities for team reflection, co-working or external supervision, could provide social workers with a wider support network for decision making. This, in turn, could help to develop skills in critical reflection and increase confidence in one's judgements. In this way, the organisational context could act as a counterbalance to other external factors, such as negative media narratives or the national child protection system itself.

\section{Limitations}

The samples from England and Finland were relatively small, and for this reason the results should be seen as illustrative, rather than definitive accounts of how social workers in the two contexts make decisions. In addition, as verbal translation was required for most of the Finnish interviews, some level of detail may have been lost from this data. This is a common problem in cross-national research (Pösö, 2014), and to mitigate this, translation support was provided by child protection researchers who were familiar with the specialist terminology.

\section{Conclusion}

The findings of this small-scale comparative study demonstrate the significance of both national and organisational contexts in child protection decision making. The study aimed to identify, first, if there were differences in how social workers in England and Finland approach their decisions. The data indicated that differences did exist between the English and Finnish samples; for example, regarding procesess for obtaining authority for decisions, a finding which supports 
JOURNAL OF SOCIAL WORK PRACTICE

COMPARING CHILD PROTECTION DECISION MAKING

existing studies that have highlighted the influence of national context on child protection decision making. As regards the second research question, what factors do social workers identify as being influences on their judgement, the results indicated that organisational systems can play a role in influencing social workers' judgements; for example, through systems of coworking or team-based supervision, both of which were more prevalent in the Finnish context. In this way, the results demonstrate that decision making in child protection is not an individual effort, but a collective process that is dependent upon complex and interacting conditions at the organisational and national levels.

Finally, the sources of support described by the English and Finnish participants appear to support a conceptualisation of two contrasting approaches to decision making: supervised and supported judgement. The apparent dominance of supervised judgement in England suggests further research is needed surrounding the possible impact this hierarchical approach may be having on social workers' reasoning and professional development. Similarly, the fact that support from managers was referred to less often in Finland could signify that managerial guidance is less accessible to Finnish social workers. Exploring whether this is the case, and whether managers themselves may be in need of more support, could help to develop our knowledge of supervisory arrangements in different child protection systems. Further research surrounding judgement and decision making in different organisational settings, both within countries and cross-nationally, would also help to develop our understanding of whether the supervised/supported judgement conceptualisation may be applicable in contexts beyond England and Finland. Given the complex role of macro- and meso-level factors in decision making, further research could additionally help to reveal whether small organisational changes, such as systems to encourage greater team discussion or joint-working, may help to foster more 
JOURNAL OF SOCIAL WORK PRACTICE

COMPARING CHILD PROTECTION DECISION MAKING

supportive decision making cultures, and in so doing, promote greater confidence in child protection decisions.

\section{Acknowledgements}

We would like to thank Professor Riitta Vornanen and Janissa Miettinen for their indispensable contribution to this study. 


\section{References}

Baumann, D. J., Dalgleish, L., Fluke, J. D., \& Kern, H. (2011). The decision-making ecology. Washington, DC: American Humane Association.

Benbenishty, R., Davidson-Arad, B., López, M., Devaney, J., Spratt, T., Koopmans, C., .. . Hayes, D. (2015). Decision making in child protection: An international comparative study on maltreatment substantiation, risk assessment and interventions recommendations, and the role of professionals' child welfare attitudes. Child Abuse \& Neglect, 49, 63-75. doi:10.1016/j.chiabu.2015.03.015

Benbenishty, R., Osmo, R., \& Gold, N. (2003). Rationales provided for risk assessments and for recommended interventions in child protection: A comparison between Canadian and Israeli professionals. British Journal of Social Work, 33(2), 137-155. doi:10.1093/bjsw/33.2.137

Berrick, Dickens, J., Pösö, T., \& Skivenes, M. (2016). Time, institutional support, and quality of decision making in child protection: A cross-country analysis. Human Service Organizations: Management, Leadership \& Governance, 40(5), 451-468. doi:10.1080/23303131.2016.1159637

Berrick, Peckover, S., Pösö, T., \& Skivenes, M. (2015). The formalized framework for decisionmaking in child protection care orders: A cross-country analysis. Journal of European Social Policy, 25(4), 366-378. doi:10.1177/0958928715594540

Braye, S., Preston-Shoot, M., \& Wigley, V. (2013). Deciding to use the law in social work practice. Journal of Social Work, 13(1), 75-95. doi:10.1177/1468017311431476

Burns, K., Pösö, T., \& Skivenes, M. (2016). Child welfare removals by the state: A cross-country analysis of decision-making systems. New York: Oxford University Press. 
JOURNAL OF SOCIAL WORK PRACTICE

COMPARING CHILD PROTECTION DECISION MAKING

Cross, S., Hubbard, A., \& Munro, E. (2010). Reclaiming social work: London Borough of Hackney Children and Young People's Services. London: London School of Economics/Human Reliability Associates.

De Bortoli, L., \& Dolan, M. (2015). Decision making in social work with families and children: Developing decision-aids compatible with cognition. British Journal of Social Work, 45(7), 2142-2160. doi:10.1093/bjsw/bcu087

Gilbert, N. (1997). Combatting child abuse: International perspectives and trends. New York: Oxford University Press.

Gilbert, N., Parton, N., \& Skivenes, M. (2011). Child protection systems: international trends and orientations. New York: Oxford University Press.

Gillingham, P., \& Humphreys, C. (2010). Child protection practitioners and decision-making tools: Observations and reflections from the front line. British Journal of Social Work, 40(8), 2598-2616. doi:10.1093/bjsw/bcp155

Hackett, S., \& Taylor, A. (2014). Decision making in social work with children and families: The use of experiential and analytical cognitive processes. British Journal of Social Work, 44(8), 2182-2199. doi:10.1093/bjsw/bct071

Hearn, J., Pösö, T., Smith, C., White, S., \& Korpinen, J. (2004). What is child protection? Historical and methodological issues in comparative research on lastensuojelu/child protection. International Journal of Social Welfare, 13(1), 28-41. doi:10.1111/j.13696866.2004.00295.x

Helm, D., \& Roesch-Marsh, A. (2017). The ecology of judgement: A model for understanding and improving social work judgements. British Journal of Social Work, 47(5), 13611376. doi:10.1093/bjsw/bcw091 
JOURNAL OF SOCIAL WORK PRACTICE

COMPARING CHILD PROTECTION DECISION MAKING

HM Government. (2015). Working together to safeguard children: A guide to inter-agency working to safeguard and promote the welfare of children. London: HMSO.

Holland, S. (1999). Discourses of decision making in child protection: conducting comprehensive assessments in Britain. International Journal of Social Welfare, 8(4), 277-287. doi:10.1111/1468-2397.00094

Keddell, E. (2014). Current debates on variability in child welfare decision-making: a selected literature review. Social Sciences, 3(4), 916-940. doi:10.3390/socsci3040916

Lorenz, W. (1994). Social work in a changing Europe. London: Routledge.

Munro, E. (2002). Effective child protection. London: Sage Publications.

Munro, E. (2011). The Munro review of child protection. Final Report: A child-centred system. London: HMSO.

Munro, E., \& Hubbard, A. (2011). A systems approach to evaluating organisational change in children's social care. British journal of social work, 41(4), 726-743. doi:10.1093/bjsw/bcr074

Parton, N. (2017). Comparing child protection systems: Towards a global perspective. In P. Dolan \& N. Frost (Eds.), The Routledge handbook of global child welfare (pp. 225-242). New York: Routledge.

Platt, D., \& Turney, D. (2014). Making threshold decisions in child protection: A conceptual analysis. British Journal of Social Work, 44(6), 1472-1490. doi:10.1093/bjsw/bct007

Pösö, T. (2014). Translation as a knowledge transformation practice- the ambiguous case of presenting Finnish child welfare in English. European Journal of Social Work, 17(5), 616-626. doi:10.1080/13691457.2014.930815 
JOURNAL OF SOCIAL WORK PRACTICE

COMPARING CHILD PROTECTION DECISION MAKING

Saltiel, D. (2016). Observing front line decision making in child protection. British Journal of Social Work, 46(7), 2104-2119. doi:10.1093/bjsw/bcv112

Soydan, H. (1995). A cross-cultural comparison of how social workers in Sweden and England assess a migrant family. International Journal of Social Welfare, 4(2), 85-93. doi:10.1111/j.1468-2397.1995.tb00084.x

Soydan, H., \& Stål, R. (1994). How to use the vignette technique in cross-cultural social work research. International Journal of Social Welfare, 3(2), 75-80. doi:10.1111/j.14682397.1994.tb00060.x

Stokes, J., \& Schmidt, G. (2012). Child protection decision making: A factorial analysis using case vignettes. Social Work, 57(1), 83-90. doi:10.1093/sw/swr007

Taylor, B. J. (2012). Models for professional judgement in social work. European Journal of Social Work, 15(4), 546-562. doi:10.1080/13691457.2012.702310

Taylor, B. J. (2017). Heuristics in professional judgement: A psycho-social rationality model. British Journal of Social Work, 47(4), 1043-1060. doi:10.1093/bjsw/bcw084

van de Luitgaarden, G. M. (2009). Evidence-based practice in social work: Lessons from judgment and decision-making theory. British Journal of Social Work, 39(2), 243-260. doi:10.1093/bjsw/bcm117

Warner, J. (2014). 'Heads must roll'? Emotional politics, the press and the death of Baby P. British Journal of Social Work, 44(6), 1637-1653. doi:10.1093/bjsw/bct039

Whittaker, A. (2011). Social defences and organisational culture in a local authority child protection setting: challenges for the Munro Review? Journal of Social Work Practice, 25(4), 481-495. doi:10.1080/02650533.2011.626654 
Table 1 Participant characteristics

\begin{tabular}{|c|c|c|c|c|c|c|c|c|c|c|}
\hline \multirow[b]{2}{*}{ Site } & \multicolumn{5}{|c|}{ England $(\mathrm{N}=15)$} & \multicolumn{4}{|c|}{ Finland $(\mathrm{N}=15)$} & \multirow[b]{2}{*}{$\begin{array}{l}\text { Overall total } \\
\text { (England and } \\
\text { Finland) }\end{array}$} \\
\hline & $\begin{array}{c}\text { Local } \\
\text { authority } 1\end{array}$ & $\begin{array}{c}\text { Local } \\
\text { authority } 2\end{array}$ & $\begin{array}{c}\text { Local } \\
\text { authority } 3\end{array}$ & $\begin{array}{c}\text { Local } \\
\text { authority } 4\end{array}$ & Total & $\begin{array}{c}\text { Municipality } \\
1\end{array}$ & $\begin{array}{c}\text { Municipality } \\
2\end{array}$ & $\begin{array}{c}\text { Municipality } \\
3\end{array}$ & Total & \\
\hline $\begin{array}{l}\text { Number of } \\
\text { participants }\end{array}$ & 4 & 7 & 3 & 1 & 15 & 4 & 9 & 2 & 15 & 30 \\
\hline $\begin{array}{l}\text { Number of } \\
\text { participants } \\
\text { (male/female) }\end{array}$ & $\begin{array}{l}2 \text { male/ } \\
2 \text { female }\end{array}$ & $\begin{array}{l}0 \text { male/ } \\
7 \text { female }\end{array}$ & $\begin{array}{l}1 \text { male/ } \\
2 \text { female }\end{array}$ & $\begin{array}{c}0 \text { male/ } \\
1 \text { female }\end{array}$ & $\begin{array}{c}3 \text { male/ } \\
12 \text { female }\end{array}$ & $\begin{array}{l}0 \text { male/ } \\
4 \text { female }\end{array}$ & $\begin{array}{l}0 \text { male/ } \\
9 \text { female }\end{array}$ & $\begin{array}{c}0 \text { male/ } \\
2 \text { female }\end{array}$ & $\begin{array}{c}0 \text { male/ } \\
15 \text { female }\end{array}$ & $\begin{array}{c}3 \text { male/ } \\
27 \text { female }\end{array}$ \\
\hline Age (range) & $\begin{array}{c}27 \text { to } 51 \\
\text { years }\end{array}$ & $\begin{array}{c}29 \text { to } 52 \\
\text { years }\end{array}$ & $\begin{array}{c}31 \text { to } 47 \\
\text { years }\end{array}$ & Unknown & $\begin{array}{c}27 \text { to } 52 \\
\text { years }\end{array}$ & $\begin{array}{c}31 \text { to } 61 \\
\text { years }\end{array}$ & $\begin{array}{c}32 \text { to } 59 \\
\text { years }\end{array}$ & $\begin{array}{c}33 \text { years } \\
\text { (1 unknown) }\end{array}$ & $\begin{array}{c}31 \text { to } 61 \\
\text { years }\end{array}$ & 27 to 61 years \\
\hline Age (average) & 38 years & 43 years & 38 years & Unknown & 40 years & 47 years & 41 years & 33 years & 42 years & 41 years \\
\hline $\begin{array}{l}\text { Post- } \\
\text { qualifying } \\
\text { experience } \\
\text { (range) }\end{array}$ & $\begin{array}{c}10 \text { months } \\
\text { to } \\
9 \text { years }\end{array}$ & $\begin{array}{c}2 \text { years to } \\
12 \text { years }\end{array}$ & $\begin{array}{l}1 \text { year to } \\
3 \text { years }\end{array}$ & 1 month & $\begin{array}{l}1 \text { month to } \\
12 \text { years }\end{array}$ & $\begin{array}{l}2 \text { years to } \\
11 \text { years }\end{array}$ & $\begin{array}{l}1 \text { month to } \\
19 \text { years }\end{array}$ & $\begin{array}{c}3 \text { months to } \\
10 \text { years }\end{array}$ & $\begin{array}{l}1 \text { month to } \\
19 \text { years }\end{array}$ & $\begin{array}{l}1 \text { month to } \\
19 \text { years }\end{array}$ \\
\hline $\begin{array}{l}\text { Post- } \\
\text { qualifying } \\
\text { experience } \\
\text { (average) }\end{array}$ & 4 years & 4 years & 2 years & 1 month & $\begin{array}{l}3 \text { years } \\
4 \text { months }\end{array}$ & 6 years & 7 years & 5 years & $\begin{array}{l}6 \text { years } \\
3 \text { months }\end{array}$ & $\begin{array}{c}4 \text { years } \\
9 \text { months }\end{array}$ \\
\hline
\end{tabular}


Table 2 Overview of case vignettes

Child/ren
details $\quad$ Parent details $\quad$ Other case details

Male, aged 6 Mother, in receipt of state benefits

Vignette 1 Female, aged 18 months, appears small for her age

Male, aged 14, Mother and father, Vignette 2 mild learning no details given in difficulties
Partner of mother, unclear if birth father referral
Referral received from a school welfare officer. The boy had appeared tired in school due to arguing at home. Mother had two children removed previously. Financial problems. Mother refused a support plan from the school.

Referral received from a youth worker. The boy shared explicit photographs of himself with another male over the internet, who the boy has not met, and who threatened to share the images. The boy is very upset and expressed suicidal thoughts. The boy does not want his parents or teachers to find out about the incident or his sexuality. 